\title{
A comparison of the effects of gravity and the nutritional advantage of leaf surfaces on fecundity in the two-spotted spider mite (Acari: Tetranychidae)
}

\author{
Yuta SAKAI, Masaaki SUDO* and Masahiro OSAKABE \\ Graduate School of Agriculture, Kyoto University; Oiwake-cho, Kitashirakawa, Sakyo-ku, Kyoto \\ 606-8502, Japan
}

(Received 20 October 2011; Accepted 14 December 2011)

\begin{abstract}
The tendency of the two-spotted spider mite, Tetranychus urticae, to lay eggs on the abaxial (lower) side of host plant leaves has been explained as an adaptation to avoid rainfall and solar ultraviolet radiation. However, differences in the nutrition and effects of gravity between the abaxial and adaxial (upper) leaf surface could affect mite fitness. We investigated the fecundity of mites using kidney bean leaf discs with their adaxial or abaxial sides facing upward or downward. Fecundity was greater on adaxial leaf surfaces and on leaf discs facing downward but did not differ between adaxial surfaces facing upward and abaxial surfaces facing downward, suggesting that the effects of gravity and nutrition compensated for each other. Consequently, although leaf surface nutrition and gravity direction affected fecundity, these factors do not explain the biased distribution of T. urticae.
\end{abstract}

Key words: Spatial distribution, habitat heterogeneity, bottom-up effects, Tetranychus urticae, Kidney bean

\section{INTRODUCTION}

The two-spotted spider mite Tetranychus urticae Koch (Acari: Tetranychidae) is a cosmopolitan, polyphagous herbivore (Helle and Sabelis, 1985; Bolland et al., 1998) that is one of the worst agricultural pests worldwide. Adult T. urticae usually inhabit the lower (abaxial) side of host plant leaves (Foott, 1963; Osakabe et al., 2006). They infest and oviposite on the upper (adaxial) side of leaves only when the abaxial population reaches saturation (Jeppson, 1975). This bias has been explained as an adaptation to avoid rainfall (Jeppson, 1975) and solar ultraviolet B (UVB) radiation (Barcelo, 1981; Ohtsuka and Osakabe, 2009). Ohtsuka and Osakabe (2009) and Sakai and Osakabe (2010) concluded that UVB was responsible for the T. urticae concentrations on the abaxial side of kidney bean Phaseolus vulgaris L. (Fabaceae) leaves.

* Corresponding author: e-mail: sudo@kais.kyoto-u.ac.jp

This study was partially supported by Grant-in-Aid for JSPS Fellows No. 23.2696 to SM from Japan Sociery for the Promotion of Science (JSPS).

DOI: $10.2300 /$ acari.21.1 
However, studies have not considered the effect of gravity, which differs between the upper and lower surfaces of plant leaves (Sudo and Osakabe, 2011). While some studies have determined that the behavior of minute animals, including tetranychids, is not affected by the direction of gravitational pull on host leaves (e.g., Yanagida et al., 2001; Kanazawa et al., 2011), $\mathrm{Li}$ and Margolies (1991) reported that the banks grass mite, Oligonychus pratensis (Banks), exhibited positive geotaxis, which contributed to the concentration of mites on the lower side of corn leaves. No studies have examined the effect of gravity on $T$. urticae fitness on host plant leaf surfaces.

To investigate how differences in the gravitational pull and other traits (e.g. nutrition) on the different sides of leaves affect fecundity, we conducted a laboratory experiment on T. urticae with kidney bean leaves as their host plant.

\section{MATERIALS AND METHODS}

\section{Mite}

The $T$. urticae used in this study were cultured on potted kidney bean plants continuously illuminated with fluorescent lights in the laboratory at a temperature between $25^{\circ} \mathrm{C}$ and $28^{\circ} \mathrm{C}$ for at least 8 years. They were a mixture of populations from several different localities in Japan.

Quiescent deutonymphal females were transferred from the stock culture to previously uninfested kidney bean leaves on water-soaked cotton in 9-cm-wide Petri dishes. The Petri dishes were kept in a laboratory at $23^{\circ} \mathrm{C}$ with a $16: 8 \mathrm{~h}$ light to dark regimen (light period: 0700-2300). They were covered with transparent plastic lids to increase the relative humidity $(\mathrm{RH})$ on the leaves, as quiescent tetranychid mites delay molting under humid conditions (Ikegami et al., 2000). At 0900 the following morning, the lids were removed and most of the virgin adult females emerged within $30 \mathrm{~min}$. The females were immediately used for the experiment.

\section{Experimental design}

The effects of gravity direction (upward or downward pull, from the mite's perspective) and leaf surface (adaxial or abaxial) on $T$. urticae fecundity were tested using $1 \times 1 \mathrm{~cm}$ kidney bean leaf discs placed in 10-cm-wide, 4-cm-deep plastic cups (Clean Cup 200B, Risupack, Japan) with a $7 \times 15 \mathrm{~cm}$ cotton band secured to the bottom of the cup with staples (Fig. 1). A $4 \times 4 \mathrm{~cm}$ hole was cut in the bottom of the cup so that the leaf discs could contact the cotton, with four leaves per apparatus, all with either the adaxial or abaxial surface facing upward.

Then, two cups were placed upward and two downward inside a 33.5-cm-long, 25-cm-wide, 5-cm-deep plastic vat. The cotton bands were dipped in distilled water to supply the leaves with water (Fig. 1). Of the two cups facing in each direction, one contained adaxial-facing leaf discs; the other had abaxial-facing leaf discs. Therefore, the experiment had a $2 \times 2$ treatment design: gravity $\times$ leaf surface. Leaves were irradiated by $40 \mathrm{~W}$ fluorescent tubes (16L8D photoperiod) that were fixed perpendicularly at $40 \mathrm{~cm}$ interval on a side wall $30 \mathrm{~cm}$ apart from the center of the vats.

On the 1st day of the experiment, one adult virgin female $T$. urticae was introduced onto each leaf disc within 2 hours of the adult emergence described above. Adult mites were removed 

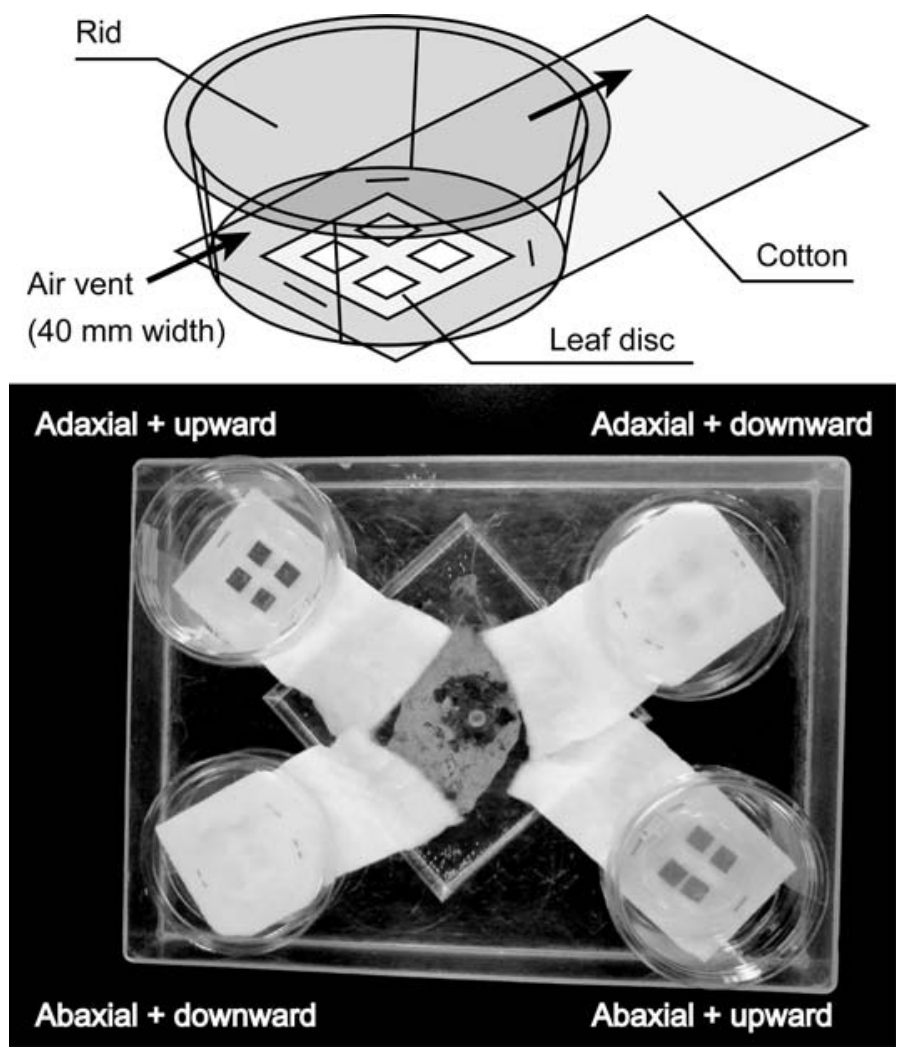

Fig. 1. The experimental equipment used to test T. urticae fecundity on the upper and lower sides of leaves facing upward or downward. Using staples, a cotton band was fixed to the bottom of the cup, where a square hole was cut. The cup had two air vents on the side.

6 days later, and the number of eggs laid on each leaf disc was counted. We prepared $128 T$. urticae mothers in eight vats, 12 of which died or escaped from the leaf discs. Data from these 12 mothers were excluded from the analysis. Consequently, the analysis included 32 females for both the adaxial leaf surfaces facing upward and downward and 27 and 25 for the abaxial leaf surfaces facing upward and downward, respectively. We used four mothers for each treatment in a batch (Fig. 1).

To assess the effects of the microclimate on the experimental equipment facing either upward or downward, we constructed equipment similar to that for the mite fecundity test with temperature/humidity data loggers (Hygrochron, KN Laboratories, Japan) instead of leaves. Temperature and RH were logged every hour for $20 \mathrm{~h}$.

We evaluated the effects of gravity and leaf side on $T$. urticae fecundity, i.e., the total number of eggs laid during the 6 days after adult emergence, with a generalized linear model (GLM) assuming a Poisson distribution (log-link) and model-selection with Akaike's information criterion (AIC). We constructed the models using the "glm" module in R (version 2.10.1; R Development Core Team 2009). 


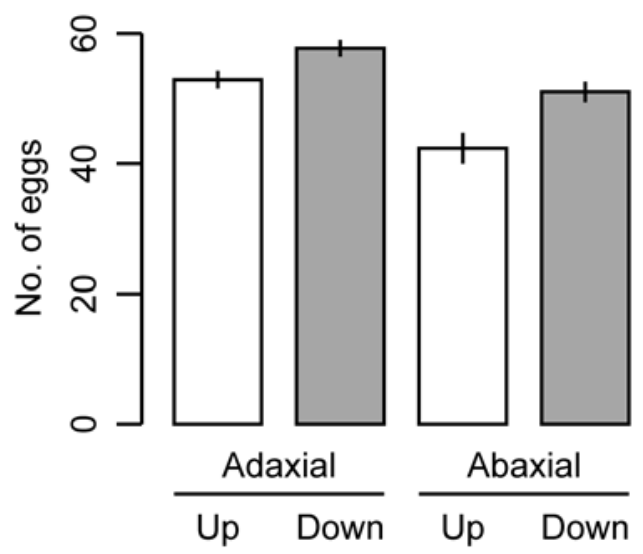

Fig. 2. The 6-day T. urticae fecundity on kidney bean leaf discs facing upward (open bars) or downward (gray bars). The vertical line on the top of the bars indicates the standard error.

\section{RESULTS AND DISCUSSION}

The 6-day T. urticae fecundity was $52.9 \pm 1.37$ and $57.7 \pm 1.29$ eggs (mean $\pm \mathrm{SE}$ ) on the adaxial leaf surfaces facing upward and downward, respectively, and $42.3 \pm 2.37$ and $51.0 \pm 1.58$ eggs on the abaxial leaf surfaces facing upward and downward, respectively (Fig. 2). The Poisson GLM and subsequent model selection supported the effects of gravity, leaf surface, and their twoway interaction on T. urticae fecundity (Table 1). The results indicate that fecundity was greater on the adaxial than abaxial leaf surfaces, concurring with the results of upward-facing leaf disk experiments conducted by Sakai and Osakabe (2010). This nutritional difference between leaf surfaces might results from difference in the thickness of epidermis (Vásquez et al., 2008) and/ or the adaxial-biased distribution of palisade mesophyll in a leaf (Tateishi, 1987). Fecundity was greater on downward-facing leaf discs than upward-facing ones. There was no temperature difference between the cups facing upward $\left(23.2 \pm 0.3^{\circ} \mathrm{C}\right.$ : mean $\left.\pm \mathrm{SD}\right)$ and downward $(23.2 \pm$ $\left.0.2^{\circ} \mathrm{C}\right)$. The relative humidity $(\mathrm{RH})$ was lower on the cups facing upward $(68.7 \pm 2.9 \%$ : mean \pm $\mathrm{SD})$ than downward $(75.4 \pm 2.6 \%)$.

Between $20-25^{\circ} \mathrm{C}$, daily spider mite fecundity is reduced only in arid $(<30 \% \mathrm{RH})$ or humid (> 85 90\% RH) climates (Boudreaux, 1958; Nickel, 1960; Boyne and Hain, 1983; Perring et al. 1984). To the best of our knowledge, there are no specific descriptions of mite fecundity variation between 60-75\% RH. Nickel (1960) reported that Tetranychus desertorum Banks fecundity did not change between $30 \%$ and $85 \%$ RH; likewise, Boyne and Hain (1983) found that the daily Oligonychus ununguis (Jacobi) fecundity did not change between low (30-40\% RH) and moderate (50-60\% RH) humidity. Therefore, the difference in $T$. urticae fecundity between the upward- and downward-facing kidney bean leaf discs was unlikely to have been caused by the humidity difference. Instead, gravity direction affected the oviposition rates.

However, when the leaf surface effect was considered, T. urticae fecundity on the adaxial leaf surfaces facing upward competed with that on the abaxial leaf surfaces facing downward. 
Table 1. The GLM (log-link, Poisson errors) results for T. urticae fecundity on kidney bean leaf discs. AIC $=875.43$ (the selected model) and 876.91 (the model lacking interactions).

\begin{tabular}{lcccc}
\hline & Estimate & Std. Error & z value & $\operatorname{Pr}(>|\mathrm{z}|)$ \\
\hline Intercept & 3.93 & 0.0280 & 140.0 & $<2.00 \times 10^{-16}$ \\
Gravity (upside) & -0.186 & 0.0407 & -4.57 & $4.82 \times 10^{-6}$ \\
Surface (adaxial) & 0.124 & 0.0364 & 3.40 & $6.77 \times 10^{-4}$ \\
Gravity $\times$ surface & 0.0986 & 0.0530 & 1.87 & 0.0620 \\
\hline
\end{tabular}

Because adaxial leaf surfaces have a nutritional advantage over abaxial surfaces, this advantage could counteract the negative effects of the upward-facing condition on the leaves of normal kidney bean plants. Therefore, despite their respective effects, gravity and nutritional quality between leaf surfaces do not explain the concentration of $T$. urticae on the lower side of kidney bean leaves under normal conditions.

\section{REFERENCES}

Barcelo, J. A. (1981) Photoeffects of visible and ultraviolet radiation on the two-spotted spider mite, Tetranychus urticae. Photochemistry and Photobiology, 33: 703-706.

Bolland, H. R., J. Gutierrez and C. H. W. Flechtmann (1998) World Catalogue of the Spider Mite Family. 392 p., Brill, Leiden.

Boudreaux, H. B. (1958) The effect of relative humidity on egg-laying, hatching, and survival in various spider mites. Journal of Insect Physiology, 2: 65-72.

Boyne, J. V. and F. P. Hain (1983) Effects of constant temperature, relative humidity, and simulated rainfall on development and survival of the spruce spider mite (Oligonychus ununguis). Canadian Entomologist, 115: 93-105.

Foott, W. H. (1963) Competition between two species of mites. II. Factors influencing intensity. Canadian Entomologist, 95: 45-57.

Helle, W. and M. W. Sabelis (1985) Spider Mites: Their Biology, Natural Enemies and Control. Vol. 1A. 458 p, Elsevier Science Publishers, Amsterdam.

Ikegami, Y., S. Yano, J. Takabayashi and A. Takafuji (2000) Function of quiescence of Tetranychus kanzawai (Acari: Tetranychidae), as a defense mechanism against rain. Applied Entomology and Zoology, 35: 339-343.

Jeppson, L. R. (1975) Chapter 2. Population ecology. In: (ed., Jeppson, L. R., H. H. Keifer and E. W. Baker) Mites injurious to economic plants. pp. 17-46, University of California Press, Berkeley, California

Kanazawa, M., K. Sahara and Y. Saito (2011) Silk threads function as an 'adhesive cleaner' for nest space in a social spider mite. Proceedings of the Royal Society B, 278: 1653-1761.

Li, J. and D. C. Margolies (1991) Factors affecting location of Banks grass mite, Oligonychus pratensis (Acari: Tetranychidae), on corn leaves. Experimental and Applied Acarology, 12: 27-34.

Nickel, J. L. (1960) Temperature and humidity relationships of Tetranychus desertorum Banks with special preference to distribution. Hilgardia, 30 (2): 41-100.

Ohtsuka, K. and Mh. Osakabe (2009) Deleterious effects of UV-B radiation on herbivorous spider mites: they can avoid it by remaining on lower leaf surfaces. Environmental Entomology, 38: 920-929.

Osakabe, M., K. Hongo, K. Funayama and S. Osumi (2006) Amensalism via webs causes unidirectional shifts of dominance in spider mite communities. Oecologia, 150: 496-505.

Perring, T. M., T. O. Holtzer, J. A. Kalisch and J. M. Norman (1984) Temperature and humidity effects on ovipositional rates, fecundity, and longevity of adult female Banks grass mites (Acari: Tetranychidae). Annals of the Entomological Society of America, 77: 581-586. 
R Development Core Team (2009) R: A language and environment for statistical computing, version 2.10.1. R Foundation for Statistical Computing, Vienna

Sakai, Y. and Mh. Osakabe (2010) Spectrum-specific damage and solar ultraviolet radiation avoidance in the two-spotted spider mite. Photochemistry and Photobiology, 86: 925-932.

Sudo, M. and M. Osakabe (2011) Do plant mites commonly prefer the underside of leaves? Experimental and Applied Acarology, 55: 25-38.

Tateishi, S. (1987) The feeding activates of the mite Tetranychus urticae (Koch) and its effects on leaf burn in the pear Pyrus communis. Journal of the Faculty of Agriculture Shinshu University, 24: 1-79. (In Japanese with an English summary).

Vásquez, C., O. Aponte, J. Morales, J. E. Sanabria and G. García (2008) Biological studies of Oligonychus punicae (Acari: Tetranychidae) on grapevine cultivars. Experimental and Applied Acarology, 45: 59-69.

Yanagida, H., Y. Saito and A. R. Chittenden (2001) Egg-depositing behavior as a predator avoidance tactic of Yezonychus sapporensis Ehara (Acari, Tetranychidae). Journal of Ethology, 19: 63-66.

\section{摘要}

葉面の表裏における栄養条件の差がナミハダニの産卵数に与える影響は重力により補償 される

酒居 勇太・須藤 正彬 * - 刑部 正博 (京大院・農)

ナミハダニが寄主葉の上面を産卵場所として利用しないことは，風雨や太陽光紫外線によ る卵への悪影響を回避するための適応だと考えられている。一方で葉面の表裏における栄養 条件の違い，および上下の葉面に扔いて虫体に掛かる重力方向の違いが，ナミハダニの適応 度に与える影響は十分に検討されていなかった。本研究ではインゲンマメのリーフディス ク（単一葉面）を用い，その表裏打よび上下がナミハダニの産卵数に与える影響を評価した. 葉表では葉裏よりも，下面では上面よりもそれぞれ産卵数が増加する傾向が支持された。 し かし「葉表かつ上面」と「葉裏かつ下面」のリーフディスク間では，これら 2 因子の影響が 打ち消し合い産卵数は拮抗した。すなわち葉面の栄養条件ないし重力方向について, 単独で のボトムアップ効果は認められるものの，ナミハダニがインゲンマメ葉の上面（葉表）に卵 を産まない理由にはならないと考えられた. 